\title{
AN ANALYSIS OF STUDENTS' DIFFICULTIES IN READING COMPREHENSION AT SMA NEGERI 1 SUKODADI LAMONGAN
}

\author{
Sulih Okta Prihatini \\ sulihokta310@gmail.com \\ Program Studi Pendidikan Bahasa Inggris, Universitas Islam Lamongan
}

\begin{abstract}
Reading is one of the four language skills taught in the English language learning process besides listening, speaking, and writing. This research aims to know the students' difficulties in reading comprehension at SMA Negeri 1 Sukodadi and to know the factors of students' difficulties in reading comprehension at SMA Negeri 1 Sukodadi. This research is descriptive qualitative research. The research was conducted in march 2020. The subject of research was the tenth-grade MIPA 5 of SMA Negeri 1 Sukodadi who were detected that they had difficulties in reading comprehension. The techniques for collecting the data were interviews and documents. the researcher collected the data such as students' worksheet. The second was data reduction. The researcher classified and reduced the data based on focus. The researcher deleted several data that did not relate to the difficulties in reading comprehension. The third was the data display, the researcher arranged the information to conclude. The researcher presented the data from the difficulties in reading comprehension, and the last is the conclusion. The result of the research showed that some students had difficulties in reading comprehension and they had difficulty in different levels, namely literal comprehension, inferential comprehension, critical comprehension, and creative comprehension. The most difficulties experienced by students were at the level of creative comprehension. The factor of the students' difficulties in comprehension at tenth grade, there was an inadequate instruction presented by the teacher, lack of pupils' interest, and the vocabulary difficulties.
\end{abstract}

Keywords: Students' Difficulties, Reading Comprehension

\section{INTRODUCTION}

Language is the most effective tool for communication with others. This is why language is very necessary for fluency in communication between language and the people who use it. People use language to express their emotions, feelings, and ideas. There are many languages in the world, one of them is English. English holds the key as an international language. Therefore mastering English is very important for all those who want to improve their knowledge and technology. English is an international language, almost everyone from all over the world uses English for their communication. That is why English is a very important language. No one will be able to communicate internationally without using English because almost all scientific books are written in English. According to Patel and Jain (2008:31),
Language is used to communicate our thoughts and ideas. Language is essential for our survival and development as a human being. Language is a result of cultural experience.

English is a foreign language for Indonesians, it is possible that students who study English having difficulty understanding in reading, because of limited understanding, or wrong reading. According to Patel and Jain (2008: 35), Foreign Languages are languages where the secondary the environment is not observed and people from foreign languages use these languages. Four language skills must be taught by English teachers at school, those are; listening, speaking, reading, and writing. In each subject, student learning activities involve reading. Reading is one way to learn 
English. Reading is important for everyone to get new knowledge.

In Indonesia, English has been taught as the first foreign language that must be learned and understood, because almost all science and technology is written in English. The Indonesian government decides English as the first foreign language, which must be taught from elementary schools to universities and even English begins to be taught to elementary school students as local content. In achieving curriculum goals there are many problems faced by teachers and students, meaning that so far the curriculum goals have not been achieved. It can be seen that many students who have completed high school cannot use English for communication both orally and in writing.

According to Oakhill, Cain, and Elbro (2015:1), Reading Comprehension is a complex task, which requires the orchestration of many different cognitive skills and abilities. It means that reading comprehension is the ability to read text, process, and understand its meaning. An individual's ability to understand the text is influenced by their natures and skills, one of which is the ability to make inferences. It means that reading comprehension is the ability to read text, process, and understand its meaning. An individual's ability to understand the text is influenced by their natures and skills, one of which is the ability to make inferences.

In reading comprehension has four levels according to Kholiq (2018) these levels are literal comprehension, inferential comprehension, critical comprehension, and creative comprehension. Literal comprehension is the ability to capture information implied in the text. Literal comprehension is a prerequisite for higher understanding (Kholiq, 2018). Inferential comprehension is the ability to understand information that is stated indirectly. According to
Kholiq (2018), Inferential comprehension is oriented to the answers that are not written in the text.

Critical comprehension is the ability to evaluate text material. Critical comprehension the same as evaluative understanding. According to Kholiq (2018), The level of critical comprehension is interpreted as the ability to read comprehension at the comparison level. Creative comprehension the ability to express emotional and aesthetic responses to texts that comply with standards or follow up after reading. According to Kholiq (2018), creative comprehension involves all cognitive dimensions of reading because it is related to the psychological and aesthetic effects of the text on the reader.

Based on the observation, in fact, the students in SMA Negeri 1 Sukodadi Lamongan have difficulties in making an inference, determining the main idea and locating reference. the researcher is interested in analyzing the students' difficulties in reading comprehension and finding out the difficultie's factors that the students face in reading comprehension. Based on the problem above, the researcher is interested in conducting research concerning students' difficulties in reading comprehension at the senior high school level.

\section{METHOD}

In this research, the researcher uses descriptive qualitative research. According to Nassaji (2015), Qualitative and descriptive research methods have been a very common procedure for researching many disciplines, including education, psychology, and social sciences. The research descriptive is done to describe systematic about the facts and characteristics of the subject (students' from SMA Negeri 1 Sukodadi Lamongan). The researcher uses descriptive design, become in this case, the research is focused on certain phenomena in the 
school environment about the difficulties of students in reading comprehension.

The subject of this research is the tenth-grade students at SMA Negeri 1 Sukodadi in Academic Year 2019/2020, and the source of data is 1. Students' Worksheet are used to see that the students have difficulty or not.. 2. Students' Answer in the Interview This interview is used to find out the factors that cause students to have difficulties.

The data analysis technique is 1 . Data Reduction the researcher chooses the DISCUSSION

\section{Students Difficulties in Reading Comprehension \\ a. The Difficulties in Literal Comprehension}

The literal comprehension of students' worksheet in understanding exploratory information in the reading. From the results of the students' worksheet, the researcher found some students' difficulties. Students could not answer written information such as:

1) Students' difficulties in Character's Identity

The students' difficulties in the character name were in number " 1 . What are the name of the writer mother? 2. What does a writer mother do? 3. What are the name of the writer? 11. What are the name of the male character in the story? 12. What does the male character do? "

From the difficulties were experienced by the students above, students had difficulty in understanding the identity of the characters in the reading. The biggest errors of students' answer were in number " 11 . What are the name of the male character in the story?" The answer should be "Toba" some students answered the questions correctly but most students answered "Lake Toba" and "Samosir", but none of the students answered "Lake". important data that had been collected. 2 . Data Display the narration of the data allows talking conclusion of the study. In present the data, the researcher describes the data in the form of description or narration. 3. Conclusion drawing/ verification conclusion of the research can be taken. The characteristic of qualitative research is analytic induction, the initial conclusion.

In literal comprehension, the answer was written in a reading. The answer was already seen in the reading in paragraph 1 and sentence 4 . This showed that the students did not careful in reading.

2) Students' Difficulties in Identity of Animal

The students' difficulties in the animal identity were in number " 21 . The literature described what kind of cat it? 22. When the cats mingle with human?"

From the difficulties were experienced by students above, students had difficulties in understanding identity in animals. The biggest errors of students' answer were in number " 21 . The literature described what kind of cat it? " The answer should be "domestic cat" some students answered the questions correctly, but some students answered, "molar", "canidae" and "premolar".

In literal comprehension, the answer was written in a reading. The answer was already seen in the reading in paragraph 1 and sentence 1 . This showed that the students did not careful in reading.

3) Students' Difficulties in Occurrence of Disaster

The students' difficulties in the disasters occur ware in number "31. How many bodies were found? 32. What day the corpse found? 33. Which country was hit by earthquake?"

From the difficulties were experienced by the students above, 
students had difficulties in reading about the occurrence of disasters. The biggest errors of students' answer were in number "31. How many bodies were found?" The answer should be "3 bodies" some students answered the questions correctly. but most students answered "14 bodies" and "5 bodies", but none of the students answered "10 bodies".

In literal comprehension, the answer was written in the text. The answer was already seen in paragraph 1 and sentence 1 . This showed that the students did not careful in reading.

b. The Difficulties in Inferential Comprehension

The inferential comprehension of students' worksheet in understanding the information implicit in reading. From the results of the students' worksheet, the researcher found some students' difficulties. Students could not answer implied information such as:

\section{1) Students' Difficulties in Problems Happened}

The students' difficulties in the problem happened ware in number " 14 . How did the early problem occur? 15. Why did the water come out of the ground ? 35. How many times earthquakes?"

The researcher found the biggest errors of students' answer ware in number "14. How did the early problem occur?" The answer should be "When the son eats all the father's food" some students answered the questions correctly. But most students answered "in the ground where they fall splash springs and when his wife and child magically disappeared", but none of the students answered, "When tell of its origin which come from the fish".

In inferential comprehension, the answer was implied in the reading. The answer was already seen in paragraph 3 and sentence 2. This showed that the students did not understand the contents of the reading.

\section{2) Students' Difficulties in Meanings} Word

The students' difficulties in the meaning of words were in number " 4 . What is the meaning of degree? 13. What is the meaning of Orphan? 24. What the meaning is domestic ? 33. What meaning of earthquake?"

The researcher found the biggest errors of students' answer ware in number " 4 . What the meaning of degree?" The answer should be "someone finished his education" some students answered the questions correctly, but some students answered "someone finished his cooking", but none of the students answered "someone finished his fishing" and "someone finished his playing".

In inferential comprehension, the answer was implied in the reading. The answer was seen in paragraph 4 and 2 . This showed that the students did not really understand the contents of the reading.

3) Students' Difficulties in Mains Idea in Reading

The students' difficulties in the main reading ideas were in number " 5 . The main idea of reading in first paragraph is ?, 25. The main idea of reading is ?, 34. Main idea of reading in first paragraph?"

The researcher found the biggest errors of students' answer was in number " 25 . The main idea of reading is?" The answer should be "the types of cat" some students answered the questions correctly, but most students answered, "Felis silvestris catus" and none of the students answered,

"The canidae" and "Domestic pain"t.

In inferential comprehension, the answer was implied in the reading. The answer was seen in paragraph 1 sentence 1 and paragraph 3 sentence 3 . This showed that the students did not understand the reading well. 
c. The Difficulties in Critical Comprehension

The critical comprehension of students' worksheet in evaluating text. From the results of the students' worksheet. The researcher found some students' difficulties. Students could not evaluate such as:

\section{1) Students' Difficulties in Correct Sentence}

The students' difficulties in the correct sentence were in number " 6 . The correct sentence in literature are? 27. The correct sentence in literature are? 37. The correct sentence in literature are?"

The researcher found the biggest errors of students' answer was in number "6. The correct sentence in literature are?" The answer should be "that she has a beautiful face" some students answered the questions correctly. But most students answered "that the mother was the person who had the most merit in the world", "Mother is the person who has the most merit in this world" and "my mother cooks me chili soup mixed with cabbage" but none of the students answered, "for me she graduated with a her book".

In critical comprehension, the answer had been determined in the reading. This answer was seen in paragraph 1 of sentence 1 . This showed that the students did not careful in reading.

2) Students' Difficulties in Incorrect Sentence

The students' difficulties in the incorrect sentences were in number, " 17 . Incorrect sentence of literature are ? 28. Incorrect sentence of literature are ? 36. Incorrect sentence of literature are?"

The researcher found the biggest errors of students' answer was in number "17. Incorrect sentence of literature are?" The answer should be "that the young man lived from farming and fishing" some students answered the questions correctly, but most students answered "the young farmer asked him to be his wife" and "the couple blessed with a girl", but none of the students answered, "He has a bad habit that is never satiated".

In critical comprehension, the answer had been determined in the reading. The answer was seen in the 1 paragraph to 3 sentences. This showed that the students' did not understand the reading well.

3) Students' Difficulties in Difference Word

The students' difficulties in the differences word were in number " 8 . What is the difference in words from hardworking and diligently working ? 16. What is the difference in words from young man and young farmer? 26. What is the difference word from domestic paint and purebred paint?"

The researcher found the biggest errors students' answer ware in number " 8 . What is the difference word from hardworking and diligently working?" The answer should be Hard working is characters and Diligently performance some students answered the questions correctly, but most students answered "diligently Working is habit and Hard working is managing time", "hard working is working and Diligently working is thought" and "Hard working is a hobby and Diligently is a work".

In critical comprehension, the answer had been determined in the reading. The answer was in paragraph 1 sentence 7 and paragraph 4 sentence 5 .
d. The Difficulties in Creative Comprehension

The creative comprehension of the ability to express emotional responses. From the results of the students' worksheet, the researcher found some students' difficulties. Students could not express emotional responses such as:
1) Students' Difficulties to Complete Overlapping Words
The students' difficulties in the overlapping words were in number "9. My 
mother is a ... who is very ... and I love this life, 18. The ... is very ..., 29. Cats are considered as "perfect ..." with ... and particular digestive tract, 38. Nepalese responders on ... found three bodies ... the wreckage of a US"

The researcher found the biggest errors of students' answer was in number "18. The ... is very ... "The answer should be "the area is very dry" some students answered the questions correctly. But some students answered "the lake is very clean", "Book and good" and "Home and lake".

In Creative comprehension, the answer was already seen in paragraph 1 and sentence 2. This showed that the students did not read carefully and students did not read to find the answered.

2) Students' Difficulties to Complete

Overlapping Sentence

The students' difficulties in overlapping sentences were in number "10. She has a beautiful face wavy black hair, round eyes, and .......... She has qualities that can make me amazed and proud to be his and make me want to be. My mother is a tough, unyielding, and patient woman. Get from a mediocre family, 19. One day the boy was eating all ...... The young man was very upset saying: "basic offspring of fish!" That statement by itself his wife with thus unlocked the secrets of their promise has been violated. 39. The second quake ....... and Mount Everest, and hit hardest in deeply rural parts of the Himalayan foothills, hammering many villages reached only by hiking trails and causing road-blocking landslides.

The researcher found the biggest errors of students' answer was in number "39. The second quake ... and Mount Everest, and hit hardest in deeply rural parts of the Himalayan foothills, hammering many villages reached only by hiking trails and causing road-blocking landslides" The answer should be "centered between Kathmandu" some students answered the questions correctly. but most students answered "were centered between the village" and "Nepal's Defense Secretary". But none of the students answered, "found three bodies".

In creative comprehension, The answer was already seen in Paragraph 4 sentence 1 . This showed that the students did not careful in reading and did not read back to find the answered.

3) Students' Difficulties in Determining the Title

The students' difficulties in determining the title were in number " 20 . Define the title of this reading? 30. Define the title of this reading ? 40. Define the title of this reading?"

The researcher found the biggest errors of students answer was in number "40. Define the title of this reading?" The answer should be "the Nepalese find 3 bodies" some students answered the questions correctly. But some students answered "the find 3 bodies" and "Tuesday that killed 117 people and injured 2,800" but none of the students answered, "the Indonesian findings find 3 bodies".

In creative comprehension, The answer was already seen in paragraph 1 of sentence 1 . This showed that the students did not read carefully and did not match the answer in reading. Kholiq (2018) states that the difficulty of students in reading comprehension had four levels there were, literal comprehension, inferential comprehension, critical comprehension, and creative comprehension. Therefore, the researcher uses these 4 levels to get students' difficulties.

Based on the results of data analysis, the researcher found that students had difficulty in all four levels. this was known from the students' worksheet contacted to the four levels and students' had difficulty in literal comprehension inquired about the name of the character's identity, animal identity and the 
occurrence of a disaster, inferential comprehension inquired about the information implicit in reading in the form of problems that occur in reading, the meaning of words and determine the main idea of reading, critical comprehension inquired about the right or wrong answered in the reading and differences of a word, and the last was creative comprehension that inquired about the words that are skipping, sentences that were skipping and determining the title of a reading

\section{Factors of Students' Difficulties in Reading Comprehension}

Based on the research finding of students' worksheet and interviews on 12th March 2020 with the tenth-grade students in SMA Negeri 1 Sukodadi, the researcher found several factors of students' difficulties in reading comprehension. There were some factors of students' difficulties such as:

1. Inadequate Instruction

The first factor of students' difficulties in reading comprehension was inadequate instruction. Based on the interviews with the students' in the tenth mipa 5 found an answered.

The researcher: "How about the teacher when teaching?"

Student : "When he teaches, he always stories about religion at length, and that makes me very confused"

The researcher: Do you ever tell to read during a reading lesson?

Student : "Never, at all, he is only being asks about questions but he never discusses"

From the interview above, the researcher found that the factor of students' difficulties also did not come from the students themselves, the teacher could also cause students' difficulties because the teacher sometimes did not explain the subject according to the topic itself, but the teacher also explained things that were far from the topic.

This was an error of instruction from the teacher when the matter should be discussed but not discuss, and in reading lessons students were never asked to read, this cause students to become unaccustomed to understand the reading.

The researcher: "How about the teacher when teaching?"

Student : "He always tells stories sometimes until the class time is over"

The researcher: "Do you ever tell to read during a reading lesson?"

Student : "Never, but he tells to do assignments in a book and never discusses it"

The researcher:" How about the teacher when teaching?"

Student : "Mostly stories"

The researcher : "Do you ever tell to read during a reading lesson?"

Student : "Never"

2. Lack of Pupil Interest

The second factor of students' difficulties in reading comprehension was lack of pupil interest. Based on the interview with the students in the tenth mipa 5 found an answered.

The researcher : "Are you interested in English lessons especially in reading?

Student : :No, because this lesson is very difficult to understand and I don't like this lesson"

From the interview above, the researcher found that the factor of students' disinterest in the lesson itself. If students were not uninterested it should be very difficult to understand the reading.

They found it difficult to understand English and the thought that causes students' to not be interested was one of the differences in the language they 
used every day with the language they had just learned.

The researcher : "Are you interested in English lessons especially reading?"

Student : "No"

The researcher : "Why?"

Student : "Because it's hard"

The researcher : "Are you interested in English lessons especially reading?"

Student : "No, I don't like to read, let especially reading English, I don't like it"

3. Vocabulary Difficulties

The third factor of students' difficulties in reading comprehension was vocabulary difficulties. Based on the interview with the students in the tenth mipa 5 found an answered.

The researcher : "Do you ever have difficulty in vocabulary"

Student :Yes, Ido. Often"

The researcher : "Why don't you use a dictionary to interpret?"

Student

"I don't have a
dictionary because I
don't like English lessons
so I don't buy a
dictionary".

From the interview above, the researcher found that the factor of students' difficulties. The students had difficulty in understanding words, and students did not use a dictionary to help them interpret words. they assumed vocabulary in English was very difficult to interpret because in one word has several meanings.

The researcher : "Do you have difficulty in vocabulary?"

$\begin{array}{ll}\text { Student } & : \text { "Yes" } \\ \text { The researcher } & : \text { "Why?" } \\ \text { Student } & \text { "Because I can't speak } \\ \text { The researcher } & \text { English" } \\ & \begin{array}{l}\text { difficulty you have } \\ \text { vocabulary?" }\end{array}\end{array}$

Student
The researcher : "Why?"

Student

: "Yes, because English vocabulary is very difficult to interpret"

Kennedy (in Sari, 2017) states that the difficulty in reading comprehension was produced by a variety of factors namely: Inadequate instruction, Lack of student interest, mismatched material, and vocabulary difficulties. Therefore, the researcher uses four factors as indicators to make interview questions.

Based on the results of the interview, the researcher only found 3 factors that influence students learning difficulties. the first factor was inadequate instruction because the teacher factor that sometimes explained out of the topic to be discussed, it caused students were uncomfortable and confused when the teacher explained because they thought that the explanation was not needed to be explained during the lesson, the second factor was lack of pupils interest Most students were less interested in reading because students were not accustomed to read when reading material, the third factor was difficulties in vocabulary, students did not translate certain words and desire to know the meaning of words other than that students also did not want to use a dictionary to find the meaning of a particular word.

\section{CONCLUSION}

Based on the explanation in the previous chapters, here the writer wants to give some conclusions of the contents of this research, it is hoped that the readers will be able to know much about this research, the conclusion such as below :

This research is conducted at the tenth-grade students of SMA Negeri 1 Sukodadi. Based on the research finding and discussion in chapter IV, it can be concluded there are some difficulties that the students still find in reading comprehension. The difficulties that students have can be seen from their 
students' worksheet. The difficulty of students in Literal Comprehension is that students cannot answer questions about the names of characters in reading and are categorized as Low Level, Difficulty of students. Inferential Comprehension is that students cannot answer the question of the meaning of a word in the reading and are categorized into Low level. The difficulty of students in Critical Comprehension is that students cannot answer questions that are true or false from a passage and are categorized in the Intermediate Level. So, that finding student difficulties are at the highest level, namely Critical Comprehension is that students cannot answer questions in the form of determining the title of a reading.

Difficulties of students in reading comprehension can be caused by 3 factors.

\section{REFERENCES}

Jane Oakhill, K. C. (2015). Understanding And Teaching Reading Comprehension. London: Routledge

Kholiq, A., \& Luthfiyati, D. (2018). Tingkat Membaca Pemahaman Siswa Sman 1 Bluluk Lamongan . Reforma: Jurnal Pendidikan dan Pembelajaran, Vol. 7 No. 1 .

Nassaji, H. (2015). Qualitative and Descriptive Research. Language Teaching Research, vol.19(2) 129132

Patel, F. M., And Jain, M. Praveen (2008). English Language Teaching . Vaishali Nagar: Sunrise Publishers \& Distributors .

Sari, Y. K. (2017 ). An Analysis Of Students' Difficulties In Comprehending English Reading Text On The Mts Negeri Mlinjon Klaten In Academic Year 2016/2017 - Islamic Institute Of Surakarta : English Education Department
The first factor is the inadequate instruction of teachers who do not accustom students to reading and the teacher sometimes explains beyond the topic being discussed, the second is the lack of pupil interest some students are not interested in reading because they are not accustomed to reading and are not accustomed to reading by their teacher. third-factor vocabulary difficulties students find it difficult to translate some words in reading but students do not want to use a dictionary to find out the meaning of words they do not know. so the factor most experienced by students is difficulties vocabulary, almost all students experience this because they do not want to find out the meaning of words they do not know.

Sugiono. (2016). metode penelitihan kuantitatif, qualitatif, dan $R \& B$. Bandung: Alfabeta. 